\title{
Continuing Professional Development of Teacher Educators: Challenges and Initiatives
}

\section{OPEN ACCESS}

Manuscript ID:

EDU-2021-09023634

Volume: 9

Issue: 2

Month: March

Year: 2021

P-ISSN: 2320-2653

E-ISSN: 2582-1334

Received: 02.12.2021

Accepted: 09.02.2021

Published: 01.03.2021

Citation:

Tyagi, Chanchal.

"Continuing Professional Development of Teacher Educators: Challenges and Initiatives." Shanlax International Journal of Education, vol. 9, no. 2, 2021, pp. 117-126.

DOI:

https://doi.org/10.34293/ education.v9i2.3634

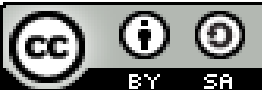

This work is licensed under a Creative Commons Attribution-ShareAlike 4.0 International License

\section{Chanchal Tyagi}

Senior Research Fellow, Department of Education

Chaudhary Charan Singh University, Meerut, Uttar Pradesh, India

https://orcid.org/0000-0003-1118-3626

\section{Pradeep Kumar Misra}

Professor, Department of Education

Chaudhary Charan Singh University, Meerut, Uttar Pradesh, India

https://orcid.org/0000-0002-9164-6071

\begin{abstract}
Continuing Professional Development (CPD) is a prerequisite for teacher educators. The importance of CPD for teacher educators lies in the fact that it helps them to improve their professional and instructional practices. Teacher educators usually begin their CPD after joining the profession and continue it as a lifelong learning process. There are two popular routes of CPD for teacher educators: programs planned and mandated by external agencies and their self-initiatives. Researchers conducted in different parts of the world reveal that, like external initiatives, selfinitiative also play an important role in the professional development of teacher educators. As part of their self-initiatives for CPD, teacher educators themselves act as the developers and creators of their professional learning opportunities and activities. Researches also depict that some factors may negatively affect teacher educators' attitude and capacity to initiate his/her CPD activities. Extending all these arguments, the present study aimed to study teacher educators' self-initiatives of CPD and the challenges they face in this journey. Data to conduct the study was collected from a sample of 120 teacher educators' by using 'Teachers' CPD Initiatives Scale' \& 'Teachers' CPD Challenges Scale', and analyzed by using percentage and product-moment $r$.
\end{abstract}

Keywords: Continuing Professional development, In-service teacher education, INSET, Teacher educators, Initiatives, Challenges

\section{Background}

There is a growing focus on the qualities of teacher educators involved in teaching the next generations of teachers (ETUCE, 2008). Because they have a direct influence on the initial training of student teachers (Furlong, et al., 2000) and for many teachers, they are role models. From them, the teachers acquire different competences, skills and values that they deploy further in their classrooms. They not only maintain and improve the quality of the education system but also develop it through their role as developers and mediators of knowledge about education and as educational innovators also (European Commission, 2013). The work of teacher educators is of such high quality and importance (Snoek, et al., 2011) that raising their quality can lead to wider improvements in education (European Commission, 2012; Buchberger, et al., 2000). How the quality of education depends on the quality of teacher educators is logically argued by Murray (as cited in Westrup, 2009): 
"The quality of teaching depends in large measure on the quality of the teachers; the quality of the teachers depends in large part upon the quality of their professional education; the quality of teacher education depends in large measure on the quality of those who provide it, namely the teacher educators".

To ensure the quality of teacher preparation programmes, teacher educators need to be involved in continuous professional development. They need to become more knowledgeable professionals than they were a year ago (Smith, 2003). As a professional group, they are increasingly aware of the need to continue to work on their competencies and the importance of being lifelong learners who keep in touch with the latest developments and insights in their field (Swennen \& Van der Klink, 2009).

Teacher educators usually begin their CPD after joining the profession and continue it as a lifelong learning process. There are two popular routes of CPD for teacher educators: programmes planned and mandated by external agencies and their selfinitiatives. Research conducted in different parts of the world reveals that, like external initiatives, self-initiatives also play an important role in the professional development of teacher educators (Al Neaimi, 2007; Mann, 2005; Richard \& Farrell, 2005). Many studies confirm that self-initiated professional development has a more positive effect on increasing the standards of professional learning (Johnson, 2006; Mann, 2005; Pettis, 2002). While programmes planned and mandated by external agencies are not available to many teacher educators, they can create professional development opportunities for themselves by taking self-initiatives like reading new books or journal articles (Phelps, 2006; Baily, et al., 2001), engaging in action research, reflecting on their teaching (Johnston, 2002; Nunan, 2001; Bartlett, 1990), and working collaboratively with their colleagues, sharing skills, experiences, and solution to common problems (Richards \& Farrell, 2005). Besides, they can also observe the classes of their colleagues, conduct researches, and evaluate teaching-learning material. Thus, there is a range of development activities that can be initiated and planned by the teacher educators themselves (Richards \& Farrell, 2005; Pettis, 2002).
The research revealed that the level of initiation for professional development activities is partially influenced by the type of challenges teacher educators encounter (Mahmoudia, \& Özkana, 2015; Avalos, 2011; Jurasaite-Harbison \& Rex, 2010). Many researchers have reported different hampering factors for CPD like time, accessibility, staff motivation, and financial issues (Geldenhuys \& Oosthuizen, 2015). Unsupportive managers, staff attitude, availability of programs, work pressure, family commitments, unsafe environments, and participation on own time are also identified as hampering factors (FernandezManzanal, et al., 2015; Drage, 2010). The intensity of these CPD hampering factors increases when there are no systematic policy provisions. The CPD of teacher educators in India often faces this situation. The other notable aspect is that available CPD policies in India treat all higher education teachers alike and do not have any distinct provisions for teacher educators, for example, NCFTE- A major policy document of teacher education does not recommend any specific CPD provisions and opportunities for teacher educators (NCTE, 2009).

Not only in India has CPD of teacher educators remained a neglected area in other countries as well. Researchers argue that little attention has been paid to this profession and little empirical evidence directly concerned with the professional learning of 'this unique occupational group' is available (Murray \& Harrison 2008; Korthagen, et al., 2005). Smith (2003) observes that "there is a wealth of information about how teachers develop professionally...but little about how teacher educators develop professionally". In the backdrop of all these observations and arguments, the present research was conducted to study the:

1. Initiatives are taken by teacher educators for practicing CPD.

2. Challenges faced by teacher educators in practicing CPD.

3. Relationship between teacher educators' CPD initiatives and challenges faced by them

\section{Hypothesis}

There is no significant relationship between teacher educators' CPD initiatives and challenges faced by them. 


\section{Methodology}

The present study was conducted on teacher educators teaching the classes of B.Ed. and M.Ed. in aided and self-finance colleges of teacher education. These colleges are affiliated with Chaudhary Charan Singh University and are spread in all the seven districts of Meerut and Saharanpur Mandal. From 10 aided and 213 self-finance colleges of teacher education, 7 aided and 14 self-finance colleges were selected using the stratified cluster random sampling method. The data was collected using the 'Teachers' CPD Initiatives Scale,' and 'Teachers' CPD Challenges Scale'. Both these scales were developed and standardized by the researchers themselves. 'Teachers' CPD Initiatives Scale' is a three-point rating scale ['Often' 'Sometimes' and 'Never'] and includes 27 items divided into 5 dimensions i.e. collaborative, reflective, constructive, digital, and financial initiatives. Teachers' CPD Challenges Scale is a five-point scale (ranging from "Strongly Agree" to "Strongly Disagree") and includes 28 items. This scale focuses on infrastructural, institutional, time managerial, psychological, unavailability of opportunities and financial type of challenges. For data analysis, percentage and product moment ' $r$ ' was calculated. To study teacher educators' CPD initiatives, the percentage was calculated for all three categories ['Often' 'Sometimes' and 'Never'] separately. In the case of teacher educators' CPD challenges, the "Strongly Agree" and "Agree" categories were merged and then the percentage was calculated for the composited categories. Both these scales were given to all the120 teacher educators working in the selected colleges. Out of these 120 , only 113 teacher educators filled both the scales completely. Therefore, the final sample size constituted 113 teacher educators.

\section{Analysis and Results}

The summary of the frequency of teacher educators taking collaborative, reflective, constructive, digital, and financial initiatives for their CPD is presented and analyzed in Tables 1,2,3,4, and 5. The summary of infrastructural, institutional, time managerial, psychological, unavailability of opportunities, and financial type of challenges they face in the practice of CPD is presented and analyzed in Tables 6, 7, 8, 9, 10, and 11. And the relationship between their CPD initiatives and the related challenges is presented in Table 12.

\section{Table 1: Collaboration based Initiatives}

\begin{tabular}{|l|c|c|c|c|c|c|}
\hline \multicolumn{1}{|c|}{ Statement } & \multicolumn{2}{|c|}{ Always } & \multicolumn{2}{l|}{ Sometimes } & \multicolumn{2}{c|}{ Never } \\
\cline { 2 - 7 } & $\mathrm{f}$ & $\%$ & $\mathrm{f}$ & $\%$ & $\mathrm{f}$ & $\%$ \\
\hline You keep track of activities of national/international teacher associations & 45 & 39.82 & 62 & 54.87 & 06 & 5.31 \\
\hline You review recently published text books/reference books & 31 & 27.43 & 72 & 63.72 & 10 & 8.85 \\
\hline You help your junior colleagues regarding professional development & 57 & 50.44 & 51 & 45.13 & 05 & 4.42 \\
\hline $\begin{array}{l}\text { You invite feedback from your colleagues on your research papers before } \\
\text { sending it to publication }\end{array}$ & 43 & 38.05 & 58 & 51.33 & 12 & 10.62 \\
\hline Your try to become member of editorial boards of different research journals & 40 & 35.39 & 43 & 38.05 & 30 & 26.55 \\
\hline
\end{tabular}

Table 1 shows that there are only $39.82 \%$ of teacher educators keep track of activities of national/ international teacher associations. Helping junior colleagues is the most popular collaborative CPD initiative among the given five but only $50.44 \%$ of teacher educators do it regularly. Only $38.05 \%$ of teacher educators take feedback from their colleagues on their research papers and $10.62 \%$ never initiate it. $35.39 \%$ of them try to become a member of editorial boards of different research journals but a large number of teacher educators (26.55\%) never try for it. Reviewing recently published textbooks/reference books is done by only $27.43 \%$ of teacher educators but $8.85 \%$ are not interested in any such activity. 
Table 2: Reflection based Initiatives

\begin{tabular}{|l|c|c|c|c|c|c|}
\hline \multicolumn{1}{|c|}{ Statement } & \multicolumn{2}{c|}{ Always } & \multicolumn{2}{c|}{ Sometimes } & \multicolumn{2}{c|}{ Never } \\
\cline { 2 - 7 } & $\mathrm{f}$ & $\%$ & $\mathrm{f}$ & $\%$ & $\mathrm{f}$ & $\%$ \\
\hline $\begin{array}{l}\text { You prepare portfolio to assess your improvement in professional } \\
\text { development }\end{array}$ & 43 & 38.05 & 53 & 46.90 & 17 & 15.04 \\
\hline You attend the classes of your senior colleagues & 37 & 32.74 & 62 & 54.87 & 14 & 12.39 \\
\hline You conduct action research for solving your particular classroom problems & 40 & 35.39 & 61 & 53.98 & 12 & 10.62 \\
\hline You note down your daily classroom experiences in a diary & 26 & 23.01 & 62 & 54.87 & 25 & 22.12 \\
\hline You discuss your classroom experiences with your colleagues & 64 & 56.64 & 45 & 39.82 & 04 & 3.54 \\
\hline $\begin{array}{l}\text { In case of facing a professional/academic problem, you consult with experts } \\
\text { of your field }\end{array}$ & 62 & 54.87 & 45 & 39.82 & 06 & 5.31 \\
\hline
\end{tabular}

Table 2 reveals that initiatives based on reflection, discussing classroom experiences with colleagues and consulting with the experts are the most initiated CPD activities (54-57\%). Maintaining a diary is the least initiated activity as only $23.01 \%$ of teacher educators practice it. The other notable observation is that $10-15 \%$ of teacher educators hardly attempt any reflection based initiation.

Table 3: Constructive Activities based Initiatives

\begin{tabular}{|l|c|c|c|c|c|c|}
\hline \multirow{2}{*}{ Statement } & \multicolumn{2}{c|}{ Always } & \multicolumn{2}{c|}{ Sometimes } & \multicolumn{2}{c|}{ Never } \\
\cline { 2 - 7 } & $\mathbf{f}$ & $\mathbf{\%}$ & $\mathbf{f}$ & $\mathbf{\%}$ & $\mathbf{f}$ & $\mathbf{\%}$ \\
\hline You write research papers/articles for magazines and newspapers & 42 & 37.17 & 53 & 46.90 & 18 & 15.93 \\
\hline You prepare instructional material for classroom use & 47 & 42.48 & 60 & 53.09 & 06 & 5.31 \\
\hline You develop online teaching learning material & 30 & 26.55 & 57 & 50.44 & 26 & 23.01 \\
\hline You submit your research proposals to different research agencies & 29 & 25.66 & 66 & 58.41 & 18 & 15.93 \\
\hline You carry out research projects & 27 & 23.89 & 62 & 54.87 & 24 & 21.24 \\
\hline
\end{tabular}

Table 3 shows that only $37.17 \%$ of teacher in developing online teaching-learning material, educators write papers or articles while preparing preparing research proposals and carrying out instructional material is limited to $42.48 \%$ of them. research projects. Surprisingly, $15-23 \%$ of teacher Only one-fourth of teachers keep themselves engage educators keep themselves away from CPD activities.

Table 4: Digital Activities based Initiatives

\begin{tabular}{|c|c|c|c|c|c|c|}
\hline \multirow{2}{*}{ Statement } & \multicolumn{2}{|c|}{ Always } & \multicolumn{2}{|c|}{ Sometimes } & \multicolumn{2}{|c|}{ Never } \\
\hline & f & $\%$ & $\mathbf{F}$ & $\%$ & f & $\%$ \\
\hline You try to get membership of online libraries of other institutions & 33 & 29.20 & 61 & 53.98 & 19 & 16.81 \\
\hline You give preference to have an account on websites of academic nature & 41 & 36.28 & 62 & 54.87 & 10 & 8.85 \\
\hline You make efforts to join online teaching communities & 38 & 33.63 & 63 & 55.75 & 12 & 10.62 \\
\hline You watch online educational programmes & 50 & 44.25 & 59 & 52.21 & 04 & 3.54 \\
\hline You listen educational discussions and debates on TV/Radio & 51 & 45.13 & 52 & 46.02 & 10 & 8.85 \\
\hline You use social media for sharing your academic experiences & 48 & 42.48 & 49 & 43.36 & 16 & 14.16 \\
\hline You take help of e-learning material in preparation of your lecture & 56 & 49.56 & 51 & 45.13 & 06 & 5.31 \\
\hline
\end{tabular}

Table 4 clarifies that activities such as watching online educational programmes, listening to educational discussions and debates, sharing academic experiences on social media, and consulting e-learning material are done by $42-49 \%$ of teacher educators. Among the selected group, $33.36 \%$ make efforts to join online teaching communities regularly and $36.28 \%$ give preference to have an account on academic websites. Data also reveals that $29.20 \%$ of teacher educators are a member of online libraries of other institutions. 
Table 5: Financial Support based Initiatives

\begin{tabular}{|c|c|c|c|c|c|c|}
\hline \multirow{2}{*}{ Statement } & \multicolumn{2}{|c|}{ Always } & \multicolumn{2}{|c|}{ Sometimes } & \multicolumn{2}{|c|}{ Never } \\
\hline & f & $\%$ & f & $\%$ & f & $\%$ \\
\hline $\begin{array}{l}\text { If your institution does not subscribe the research journals of } \\
\text { your choice, you subscribe it by yourself }\end{array}$ & 50 & 44.25 & 52 & 46.02 & 11 & 9.73 \\
\hline You buy books, to cater your CPD needs & 56 & 49.56 & 52 & 46.02 & 05 & 4.42 \\
\hline You participate in paid online professional development courses & 28 & 24.78 & 62 & 54.87 & 23 & 20.35 \\
\hline You purchase learning material of your need & 61 & 53.98 & 48 & 42.48 & 04 & 3.54 \\
\hline
\end{tabular}

According to table 5, 44-53\% of teacher educators spend money on their own for purchasing journals, books and other related learning materials. $24.78 \%$ thought of attending such courses.

Table 6: Infrastructural Challenges

\begin{tabular}{|l|c|c|c|c|c|c|}
\hline \multicolumn{1}{|c|}{ Statement } & SA & $\mathbf{A}$ & $\begin{array}{c}\text { Composite } \\
(\mathbf{S A + A})\end{array}$ & $\mathbf{\%}$ & $\mathbf{N}$ & $\%$ \\
\hline $\begin{array}{l}\text { The library of your institution does not subscribe adequate } \\
\text { e-journals / Journals }\end{array}$ & 17 & 32 & 49 & 43.36 & 17 & 15.04 \\
\hline $\begin{array}{l}\text { Teachers in your institution have no access to institutional } \\
\text { internet facility }\end{array}$ & 12 & 25 & 37 & 32.74 & 15 & 13.27 \\
\hline $\begin{array}{l}\text { Due to lack of personal cabin or separate place for you to sit and } \\
\text { work in institution, you are not comfortable in carrying out CPD } \\
\text { activities there }\end{array}$ & 13 & 38 & 51 & 45.13 & 16 & 14.16 \\
\hline Computer facility for teachers in your institution is inadequate & 12 & 31 & 43 & 38.05 & 15 & 13.27 \\
\hline
\end{tabular}

Table 6 reflects that only $38 \%$ of teacher educators have computer facilities in the institution they served and $32.74 \%$ of them also have internet access in their institutions. $45.13 \%$ of teacher educators personal cabin or separate place to sit and work in an institution and $43.36 \%$ report that their institutional library does not subscribe to the adequate number of cannot engage in their CPD. They don't have a e-journals/print journals.

Table 7: Institutional Challenges

\begin{tabular}{|c|c|c|c|c|c|c|}
\hline Statement & SA & $\mathbf{A}$ & $\begin{array}{c}\text { Composite } \\
(\mathbf{S A}+\mathbf{A})\end{array}$ & $\%$ & $\mathbf{N}$ & $\%$ \\
\hline $\begin{array}{l}\text { Management of your institution detain your salary if you take leave } \\
\text { for attending CPD activities }\end{array}$ & 13 & 13 & 40 & 35.39 & 23 & 20.35 \\
\hline Your institution is reluctant in terms of arranging CPD activities & 17 & 17 & 49 & 43.36 & 24 & 21.24 \\
\hline $\begin{array}{l}\text { Your institution does not provide you spare time to go to library and } \\
\text { study }\end{array}$ & 14 & 14 & 47 & 41.59 & 12 & 10.62 \\
\hline Your institution does not grant you leave to attend CPD activities & 13 & 13 & 47 & 41.59 & 20 & 17.69 \\
\hline $\begin{array}{l}\text { Your institutional library does not provide you CPD literature as per } \\
\text { your demand }\end{array}$ & 09 & 09 & 49 & 43.36 & 17 & 15.04 \\
\hline
\end{tabular}

$41.59 \%$ of teacher educators report that neither their institutions grant leave to attend CPD activities nor provide the spare time to study during working hours. $35.39 \%$ reported that their institution detains their salary in lieu of granting leave to attend CPD programmes / activities. $43.36 \%$ of teacher educators are of the view that their institutions are reluctant in arranging CPD activities for them and have a complaint about the unsupportive attitude of the institutional library. 
Table 8: Time Management Challenges

\begin{tabular}{|c|c|c|c|c|c|c|}
\hline Statement & SA & $\mathbf{A}$ & $\begin{array}{c}\text { Composite } \\
(\mathrm{SA}+\mathbf{A})\end{array}$ & $\%$ & $\mathbf{N}$ & $\%$ \\
\hline You don't have enough time to get engaged in CPD activities & 9 & 35 & 44 & 38.94 & 16 & 14.16 \\
\hline $\begin{array}{l}\text { There is often a conflict between your work schedule and CPD } \\
\text { activities }\end{array}$ & 9 & 43 & 52 & 46.02 & 24 & 21.24 \\
\hline $\begin{array}{l}\text { You cannot have spare time at home for CPD due to family } \\
\text { responsibilities }\end{array}$ & 10 & 38 & 48 & 42.48 & 25 & 22.12 \\
\hline $\begin{array}{l}\text { You are unable to practice CPD due to extra workload given } \\
\text { by institution }\end{array}$ & 10 & 28 & 38 & 33.63 & 18 & 15.93 \\
\hline
\end{tabular}

Table 8 shows that $33-46 \%$ teacher educators responsibilities consume their spare time, and suffer from time constraint to practice CPD, 33.63\% of them complain about extra workload in $46.02 \%$ complain that their work schedule and CPD the institutions resulting nonpractice of CPD. activities often conflicts, $42.48 \%$ tell that family

Table 9: Psychological Challenges

\begin{tabular}{|l|c|c|c|c|c|c|}
\hline \multicolumn{1}{|c|}{ Statement } & SA & $\mathbf{A}$ & $\begin{array}{c}\text { Composite } \\
\text { (SA+A) }\end{array}$ & \% & N & \% \\
\hline $\begin{array}{l}\text { You are satisfied with your present position and do not need to get } \\
\text { engaged in CPD }\end{array}$ & 10 & 29 & 39 & 34.51 & 17 & 15.04 \\
\hline You need not to learn more as you are already settled in your job & 14 & 14 & 28 & 24.78 & 08 & 7.08 \\
\hline $\begin{array}{l}\text { Professional development activities are useless because they do } \\
\text { not help in salary increment }\end{array}$ & 09 & 19 & 28 & 24.78 & 20 & 17.69 \\
\hline $\begin{array}{l}\text { You do not engage in CPD activities as they are not related to your } \\
\text { promotion }\end{array}$ & 10 & 22 & 32 & 28.32 & 18 & 15.93 \\
\hline $\begin{array}{l}\text { A specific time period should be allotted to CPD activities only } \\
\text { within working hours }\end{array}$ & 16 & 42 & 58 & 51.33 & 19 & 16.81 \\
\hline $\begin{array}{l}\text { You are teaching very well even without being engaged in CPD } \\
\text { activities }\end{array}$ & 07 & 41 & 48 & 42.48 & 28 & 24.78 \\
\hline Your spare time is for your family and not for CPD & 08 & 27 & 35 & 30.97 & 31 & 27.43 \\
\hline
\end{tabular}

A look at Table 9 reveals that $24-34 \%$ of teacher educators view CPD activities useless as these activities do not help them in salary increment or promotion and also of the view that they do not need to engage in CPD as they are already settled and report that they are teaching well even without CPD. For $30.97 \%$ of teacher educators, spending time with their family is more important than their CPD. And $51.33 \%$ of them demand that CPD activities must take place only during working hours.

satisfied with their present position. $42.48 \%$ of them 
Table 10: Lack of Opportunities

\begin{tabular}{|l|c|c|c|c|c|c|}
\hline \multicolumn{1}{|c|}{ Statement } & SA & $\mathbf{A}$ & $\begin{array}{c}\text { Composite } \\
\text { (SA+A) }\end{array}$ & $\mathbf{\%}$ & $\mathbf{~ N ~}$ & $\mathbf{\%}$ \\
\hline $\begin{array}{l}\text { Programmes organized by nearby institutions are not useful to } \\
\text { fulfill your CPD needs }\end{array}$ & 12 & 26 & 38 & 33.63 & 28 & 24.78 \\
\hline CPD activities for teachers rarely takes place in nearby places & 12 & 27 & 39 & 34.51 & 28 & 24.78 \\
\hline $\begin{array}{l}\text { You face difficulties in getting selected as a participant in CPD } \\
\text { activities }\end{array}$ & 12 & 27 & 39 & 34.51 & 28 & 24.78 \\
\hline $\begin{array}{l}\text { Professional development activities are organized mainly for } \\
\text { teachers of government institution }\end{array}$ & 09 & 30 & 39 & 34.51 & 20 & 17.69 \\
\hline
\end{tabular}

Table 10 shows that $34.51 \%$ of teacher educators report the unavailability of $\mathrm{CPD}$ opportunities in nearby places and face difficulties in getting selected that these activities are organized mainly for teachers of government institutions. At the same time, $33.63 \%$ of teacher educators complain about the uselessness as participants and complain. They also complain of available CPD activities.

Table 11: Financial Challenges

\begin{tabular}{|c|c|c|c|c|c|c|}
\hline Statement & SA & $\mathbf{A}$ & $\begin{array}{c}\text { Composite } \\
(\mathbf{S A}+\mathbf{A})\end{array}$ & $\%$ & $\mathbf{N}$ & $\%$ \\
\hline $\begin{array}{l}\text { There is no travelling allowance for you to attend professional } \\
\text { development activities }\end{array}$ & 14 & 34 & 48 & 42.48 & 23 & 20.35 \\
\hline Participation in CPD is expensive for you & 08 & 34 & 42 & 37.17 & 20 & 17.69 \\
\hline $\begin{array}{l}\text { Your institution does not reimburse the registration fee of your } \\
\text { CPD participation }\end{array}$ & 14 & 33 & 47 & 41.59 & 29 & 25.67 \\
\hline $\begin{array}{l}\text { You find it difficult to engage in CPD activities due to } \\
\text { financial constraints }\end{array}$ & 09 & 36 & 45 & 39.82 & 19 & 16.81 \\
\hline
\end{tabular}

From Table 11, it is clear that $37-39 \%$ of teacher educators find participation in CPD activities expensive and $42.48 \%$ of teacher educators report that they are not provided any traveling allowances to attend different CPD activities in other places. While $41.59 \%$ complain that their institutions do not reimburse the registration fee for attending CPD programmes.

Table 12: Relationship between Teacher Educators' CPD Initiatives and Challenges

\begin{tabular}{|l|c|c|c|}
\hline Name of Variables & $\mathbf{N}$ & $\mathbf{r}$ & $\begin{array}{c}\text { Level of } \\
\text { Significance }\end{array}$ \\
\hline $\begin{array}{l}\text { Teacher Educators' } \\
\text { Initiatives for CPD }\end{array}$ & 113 & & \\
\cline { 1 - 2 } $\begin{array}{l}\text { Teacher Educators' } \\
\text { Challenges in CPD }\end{array}$ & 113 & .07 & .05 \\
\hline
\end{tabular}

Table value with $\mathrm{df}(111)$ at $.05=.195$

Calculated value $=.07<.195$
Table 12 shows no significant correlation between teacher educators' CPD initiatives and the challenges they face. The probable reason for acceptance of this null hypothesis may be that certain factors or challenges may partially affect the professional development of teacher educators but the major role is played by their willingness to take their responsibility for their CPD.

\section{Discussion and Conclusion}

On the basis of the above presented analysis and results, it can be concluded that teacher educators need to increase their CPD initiatives. On an encouraging note, $50-56 \%$ of teacher educators are engaged in helping junior colleagues, discussing with colleagues on educational issues, consulting with experts, and purchasing teaching material. Besides, $42-49 \%$ of teacher educators are engaged in the preparation of instructional material, consulting on-line learning material, use of social media for academic discussions, and watching and listening 
to educational programmes. On the flip side, quite a less number of teacher educators are involved in other important CPD initiatives. A considerable number of teacher educators hardly take initiation to engage in such activities. These findings support the earlier observations by Bolitho and Padwad (2013) that teachers' initiatives regarding CPD are poor both in quantity and quality in India. This situation may be attributed to the restricted view of CPD which prompt teacher educators to believe that their CPD is the state responsibility and cannot do anything on their own (Bolitho \& Padwad, 2013).

At the institutional and infrastructural level, many teacher educators were found facing several challenges regarding availability and access to CPD opportunities. Not getting paid leaves to practice CPD is an issue for many teacher educators (35.39\%). No availability of relevant CPD opportunities in nearby places is also a big challenge for many teacher educators, as reported by other studies (Davi \& Bwisa, 2013; Opfer \& Pedder, 2010). Time constraint in terms of extra workload (33.63\%) (supported by studies of Van der Klink, et al., 2017; Davi \& Bwisa, 2013), and conflict between work schedule and CPD activities (46.02\%) was found as other major factors that hamper the CPD participation of teacher educators. Further, a considerable number of teacher educators were found to be facing financial constraints to practice CPD (also reported by Davi \& Bwisa, 2013). Above all, psychological challenges emerged as the most striking challenge as many teacher educators believe that CPD activities should be practiced only during working hours $(51.33 \%)$ as their spare time is for their families $(30.97 \%)$.

Some of the teacher educators reported that CPD activities are useless for them because these do not help to get salary increment or promotion, and some of them do not engage in CPD as they are satisfied with their present position and knowledge. Adding to this, many teacher educators were found neutral in their responses to the given statements in 'Teachers' CPD Challenges Scale' which reflects that either they are not aware or they hardly about their CPD. Findings further revealed no relationship between teacher educators' CPD initiatives and the related challenges as CPD initiatives are much likely to be affected by the responsibility and the intrinsic motivation a teacher has for his professional development (Van der Klink, et al., 2017). In all, it can be said that the findings of this study covers a small sample and cannot be generalized but presents a first look at the issue of CPD of teacher educators. More exhaustive data on this aspect will help present a comprehensive and clear picture of what teacher educators do for their professional development and what factors negatively affect their professional learning.

\section{References}

Al Neaimi, Jehan Ahmed. Professional Development for Teachers of English in the UAE. American University of Sharjah, 2007.

Avalos, Beatrice. "Teacher Professional Development in Teaching and Teacher Education over Ten Years." Teaching and Teacher Education, vol. 27, no. 1, 2011, pp. 10-20.

Bailey, Kathleen M., et al. Pursuing Professional Development: The Self as Source. Heinle \& Heinle, 2001.

Bartlett, L. "Teacher Development through Reflective Teaching." Second Language Teacher Education, edited by Jack C. Richards and David Nunan, Cambridge University Press, 1990.

Bolitho, Rod, and Amol Padwad. Continuing Professional Development: Lessons from India. British Council, 2013.

Buchberger, F., et al. Green Paper on Teacher Education in Europe. Thematic Network on Teacher Education in Europe, 2000.

David, M. N. and H.M. Bwisa. "Factors Influencing Teachers' Active Involvement in Continuous Professional Development: A Survey in Trans Nzoia West District, Kenya." International Journal of Academic Research in Business and Social Sciences, vol. 3, no. 5, 2013.

Drage, Karen. "Professional Development: Implications for Illinois Career and Technical Education Teachers." Journal of Career and Technical Education, vol. 25, no. 2, 2010, pp. 24-37. 
Fernandez-Manzanal, Rosario, et al. "Environmental Behaviors in Initial Professional Development and their Relationship with University Education." Journal of Cleaner Production, vol, 108, 2015, pp. 830-840.

Furlong, John, et al. "Redefining Partnership: Revolution or Reform in Initial Teacher Education?." Journal of Education for Teaching, vol. 22, no. 1, 1996, pp. 39-56.

Geldenhuys, Johanna L., and Lizette C. Oosthuizen. "Challenges Influencing Teachers' Involvement in Continuous Professional Development: A South African Perspective." Teaching and Teacher Education, vol. 51, 2015, pp. 203-212.

Johnson, Karen E. "The Sociocultural Turn and its Challenges for Second Language Teacher Education." TESOL Quarterly, vol. 40, no. 1, 2006, pp. 235-257.

Johnston, Bill. Values in English Language Teaching. Lawrence Erlbaum Associates Publishers, 2003.

Jurasaite-Harbison, Elena, and Lesley A. Rex. "School Cultures as Contexts for Informal Teacher Learning." Teaching and Teacher Education, vol. 26, 2010, pp. 267-277.

Korthagen, F., et al. "Teaching Teachers-Studies into the Expertise of Teacher Educators: An Introduction to this Theme Issue." Teaching and Teacher Education, vol. 21 no. 2, 2005, pp. 107-115.

Mahmoudia, Farzaneh, and Yonca Özkan. “Exploring Experienced and Novice Teachers' Perceptions about Professional Development Activities." Procedia - Social and Behavioral Sciences, vol. 199, 2015, pp. 57-64.

Mann, Steve. "The Language Teacher's Development." Language Teaching, vol. 38, 2015, pp. 103-118.

Murray, Jean., and Jennifer Harrison. "Editorial." European Journal of Teacher Education, vol. 31, no. 2, 2008, pp. 109-115.

Nunan, David. "Action Research in Language Education." Innovation in English Language Teaching: A Reader, edited by David R. Hall and Ann Hewings, Routledge, 2001, pp. 197- 207.
Opfer, V. Darleen, and David Pedder. "Access to Continuous Professional Development by Teachers in England." The Curriculum Journal, vol. 21, no, 4, 2010, pp. 453-471.

Pettis, Joanne. "Developing Our Professional Competence: Some Reflections." Methodology in Language Teaching: An Anthology of Current Practice, edited by Jack C. Richards and Willy A. Renandya, Cambridge University Press, 2002, pp. 393-396.

Phelps, Patricia H. "The Three Rs of Professionalism." Kappa Delta Pi Record, vol. 42, no. 2, 2006, pp. 69- 71.

Richards, Jack C., and Thomas S.C. Farrell. Professional Development for Language Teachers: Strategies for Teacher Learning. Cambridge University Press, 2005.

Smith, Kari. "So, What about the Professional Development of Teacher Educators?" European Journal of Teacher Education, vol. 26, no. 2, 2003, pp. 201-215.

Snoek, Marco. "The Quality of Teacher Educators in the European Policy Debate: Actions and Measures to Improve the Professionalism of Teacher Educators." Professional Development in Education, vol. 37, no. 5, 2011, pp. 651-664.

Srinivasacharlu, A. "Continuing Professional Development (CPD) of Teacher Educators in 21st Century." Shanlax International Journal of Education, vol. 7, no. 4, 2019, pp. 29-33.

Supporting Teacher Educators for Better Learning Outcomes. European Commission, 2013.

Supporting the Teaching Professions for Better Learning Outcomes. European Commission, 2012.

Swennen, Anja, and Van der Klink, Marcel. "Epilogue: Enhancing the Profession of Teacher Educators." Becoming a Teacher Educator, edited by Anja Swennen and Marcel van der Klink, Springer, 2009, pp. 219-225.

Teacher Education in Europe. ETUCE Policy Paper, 2008, https://www.csee-etuce.org/images/ attachments/ETUCE_PolicyPaper_en.pdf. 
Van der Klink, Marcel. "Professional Development Westrup, Becca. "The Professional Development of Teacher Educators: What Do They Do? Needs of Teacher Educators in Higher Findings from an Explorative International Study." Professional Development in Education, vol. 43, no. 2, 2017, pp. 163-178. Education Institutions (HEIs) and Schoolbased Mentors in Schools." Advance HE, 2009.

\section{Author details}

Chanchal Tyagi, Senior Research Fellow, Department of Education, Chaudhary Charan Singh University, Meerut, Uttar Pradesh, India, Email ID: chanchaltyagi06@gmail.com

Pradeep Kumar Misra, Professor, Department of Education, Chaudhary Charan Singh University, Meerut, UttarPradesh, India, Email ID: pradeepmsr@yahoo.co.in 